\title{
Dependencia de la velocidad del pulso ultrasónico con el contenido de agua libre en la estructura de hormigón en condiciones de clima tropical
}

\author{
Dependence of ultrasonic pulse propagation velocity on free water \\ content in concrete structure under tropical climate conditions
}

\author{
C. Rodríguez Fadragas ${ }^{(*)}$, M. Rodríguez González ${ }^{(*)}$
}

Recepción/Received: 9-VII-10

Aceptación/Accepted: 14-III-11

Publicado online/Online publishing: 20-VI-11

\section{RESUMEN}

Una de las aplicaciones fundamentales del método de la velocidad del pulso ultrasónico (VPU) en el estudio del hormigón consiste en la estimación de las propiedades mecánicas. La precisión en la estimación de estas propiedades puede depender de la incidencia de varios factores, uno de ellos es el contenido de agua libre que adquiere la muestra de hormigón en las condiciones de trabajo. El propósito de este trabajo es mostrar que la modelación de la dependencia entre la velocidad de propagación del pulso ultrasónico y el contenido de agua libre en el hormigón endurecido requiere de un enfoque no lineal. Se plantean dos modelos: un modelo matemático no lineal que se ajusta a los datos experimentales y un modelo físico simple estructurado a partir de considerar al hormigón como un material heterogéneo. Además, se discute bajo qué condición es posible utilizar el enfoque de modelación lineal propuesto por otros autores.

Palabras claves: velocidad del pulso ultrasónico, hormigón, modelación, contenido de agua.

\section{SUMMARY}

One of the fundamental applications of the ultrasonic pulse velocity method (UPV) to the study of concrete consists in the estimation of the mechanical properties. The precision on the estimation of theses properties may be dependent on the incidence of several factors, one of them is the free water content absorbed by the sample of concrete under working conditions. In this paper it is shown that the modeling of the dependence between the ultrasonic pulse velocity and the content of free water in the hardened concrete requires the non linear approach. We propose two models, one of them being a non linear mathematical model fitting the experimental data points, and the other of them being a simple physical model structured by considering the concrete material as composed as heterogeneous medium. Besides, it is discussed under which condition the linear approach for modelling proposed by other authors can be used.

Keywords: ultrasonic pulse velocity, water content, concrete, modeling.

(*) Universidad Central de Las Villas (Santa Clara, Cuba). 


\section{INTRODUCCIÓN}

El desarrollo de la industria de la construcción ha exigido el perfeccionamiento de métodos no destructivos más eficaces y económicos de inspección que permitan un control más eficiente y confiable. Uno de estos métodos está basado en la medición de la velocidad del pulso ultrasónico (1-3). No obstante, para que la aplicación de este método sea más eficaz es necesario el conocimiento de ciertos factores que afectan, directa o indirectamente, la velocidad de propagación del pulso ultrasónico (4). Uno de estos factores es precisamente el contenido de agua libre en el hormigón, en función del cual la velocidad de propagación del pulso ultrasónico y la resistencia a la compresión tienen comportamientos diferentes $(5,6)$. Bajo las condiciones ordinarias de clima tropical, el hormigón en obra se expone a altos niveles de humedad, lo cual ha motivado el estudio del problema que se presenta en este trabajo.

En algunos trabajos $(7,8)$ se ha analizado la incidencia del contenido de agua libre sobre la velocidad del pulso ultrasónico. El objetivo de este trabajo es mostrar que la modelación de la dependencia de la velocidad de propagación del pulso ultrasónico y el contenido de agua libre en los espacios porosos del hormigón endurecido requiere de un enfoque no lineal. Se retoman los datos publicados en (7) y primeramente se presenta un modelo matemático no lineal que se confirma estadísticamente, el cual describe adecuadamente el comportamiento de la velocidad en función del contenido de agua libre en el concreto. Posteriormente se propone un modelo físico simple no lineal basado en principios físicos y geométricos de la propagación del pulso ultrasónico en el hormigón, donde este medio se representa como un material compuesto, formado por tres capas o fases: la sólida, la líquida y la gaseosa.

Además, se analiza bajo qué condición es posible utilizar el modelo lineal propuesto por (7) para describir el comportamiento de la velocidad del pulso ultrasónico con el contenido de agua libre. Resulta de gran interés valorar cómo la condición de clima tropical puede modificar el valor de la velocidad del pulso ultrasónico debido a la presencia de agua libre en la estructura.

\section{PARTE EXPERIMENTAL}

Se utilizan los datos experimentales publicados en (7), donde se utilizaron probetas cilíndricas de $200 \mathrm{~mm}$ x $100 \mathrm{~mm}$ para tres dosificaciones diferentes. Las probetas son sumergidas en agua 50 días hasta alcanzar la saturación. Posteriormente en estado saturado cada probeta es situada en una cámara de secado para medir la variación de su

\section{INTRODUCTION}

The development of the construction industry has required to elaborating more effective methods of nondestructive inspection and financial control to allow a more efficient and reliable industrial performance. One of these methods is based on the measurement of ultrasonic pulse velocity (1-3). However, for the application of this method a higher efficient is required to be aware of certain factors that affect, directly or indirectly, the velocity of ultrasonic pulse propagation (4). One of these factors is the content of free water in concrete structures, in terms of which the propagation velocity of ultrasonic pulse and compression strength have different behaviors $(5,6)$. Under ordinary conditions of tropical climate the concrete structures are exposed to a high level of moisture, which has motivated the study of the problem presented in this paper.

The impact of free water content on the ultrasonic pulse velocity has been analyzed in some works $(7,8)$. The aim of this paper is to show that for modeling the dependence of the propagation velocity of ultrasonic pulse with the free water content in hardened concrete pore spaces a nonlinear approach is required. The experimental data points published in (7) were considered here and a nonlinear mathematical model, statistically confirmed, for fitting those points was proposed. This model adequately describes the behavior of the propagation velocity of the ultrasonic pulse as a function of the free water content in the concrete structure. Next, a physical nonlinear model based on geometric and physical principles for describing the propagation of the ultrasonic pulse in concrete was proposed, where the concrete is represented as a composite material consisting of three layers or phases: solid, liquid and gaseous.

In addition, it was analyzed under which condition it is possible to use the linear model proposed by (7) to describe the behavior of the ultrasonic pulse velocity with the content of free water. It is very interesting to assess how the condition of tropical climate can change the value of the ultrasonic pulse velocity due to the presence of free water in the structure without modifying the value of the compression strength of the material.

\section{EXPERIMENTAL PART}

The experimental data points published in (7) were again considered. There cylindrical testing pieces $200 \mathrm{~mm} \times 100 \mathrm{~mm}$ for three different dosages, called A1, B1, and $C 1$, were used. The testing pieces were immersed in water during 50 days until saturation was achieved. Next, each testing piece was placed over a balance inside a drying chamber for 
masa. El contenido de agua libre $\left(m_{w}\right)$ en la probeta se define como el porcentaje en peso con relación al estado totalmente seco. Se toman 15 valores de $m_{w}$ en cada dosificación. Se mide cinco veces el tiempo de propagación del pulso ultrasónico para cada valor del contenido de agua libre obteniéndose cinco valores de la velocidad de propagación. Se acoplan los transductores utilizando el método de transmisión permitiendo medir el valor de la velocidad del pulso ultrasónico en función del contenido de agua libre.

\section{RESULTADOS}

Se presentan los dos modelos estudiados para el ajuste de los datos experimentales. Teniendo en cuenta el cálculo de la probabilidad de la bondad de ajuste que en todos los casos no hay diferencias significativas entre las réplicas para un nivel de significación del 5\%, se trabaja con los valores medios de las réplicas lo que permite lograr un mejor ajuste del modelo. Se propone un modelo de carácter matemático propiamente y el otro surge a partir de consideraciones físicas y geométricas para la propagación del rayo ultrasónico en el material.

\subsection{Modelo matemático}

Observándose el comportamiento de los datos experimentales en cada una de las dosificaciones y tendiendo en cuenta el carácter no lineal del proceso de absorción y desorción de la humedad en materiales porosos (9-13), se propone el modelo matemático siguiente [1]: eliminating continuously the moisture in the testing piece, and its mass was measured in certain selected instants of time. The content of free water $\left(m_{w}\right)$ in the testing piece in a given instant of time was determined as the difference of its mass measured in that instant and its mass measured in dried state. The traveling time of the ultrasonic pulse in the testing piece was measured five times for each value of the content of free water. Transducers were coupled by using the transmission method allowing to measure the value of the traveling time of the ultrasonic pulse through the testing piece as a function of free water content.

\section{RESULTS}

The two models proposed for fitting the experimental data points are discussed here. Taking into account the estimation of the probability of fitting flexibility of each model no significant difference between the replicas for a significance level of $5 \%$ were found in any case. It allows us to working with average values of the replicas and provides a better fitting of the model to the experimental data points. We proposed a mathematical model and the other one arises from physical and geometrical considerations on the propagation of ultrasonic beam in the material.

\subsection{Mathematical Model}

By noticing the performance of the experimental data for each dosage and by bearing in mind the non linear absorption and desorption processes of moisture in porous materials (9-13), the following mathematical model was proposed [1]:

$$
\frac{d V}{d C}=k\left(V_{0}-V\right)
$$

Cuya solución es [2]:

and the solution is [2]:

$$
V=V_{0}+A_{0} e^{-C / K}
$$

donde $A_{0}$ ( $A$ en la salida ) y $K$ ( $1 / \mathrm{K}$ en la salida ) son parámetros del modelo, $\mathrm{V}$ es la velocidad estimada, $\mathrm{Vo}\left(\mathrm{y}_{0}\right.$ en la salida) que representa la velocidad en del pulso en la muestra en estado saturado y $\mathrm{C}$ es el contenido de agua libre.

\subsection{Modelo físico simple}

Se realiza una modelación física simple para derivar una fórmula de ajuste a los datos experimentales obtenidos en (7). Un haz de rayos ultrasónicos que viaja a través de una muestra de hormigón que contiene agua libre puede ser modelado mediante la consideración de un esquema equivalente a un medio heterogéneo estratificado, where $A_{0}$ ( $A$ in the statistical outcome) and $k(1 / K$ in the statistical outcome) are parameters of the model, $V$ is the estimated velocity, $V_{0}$ ( $y_{0}$ in the statistical outcome) represents the velocity of the ultrasonic pulse in saturated state of the testing piece, and $C$ is the content of free water.

\subsection{Simple physical model}

A physical simple modeling was proposed for deriving a fitting formula that fits the experimental data points obtained in (7). An ultrasonic ray travelling through a concrete testing piece containing free water can be modeled by considering an equivalent scheme consisting of a heterogeneous medium composed by three phases 
compuesto por tres capas: fase gaseosa (aire), fase líquida (agua libre), y fase sólida (agregados finos y gruesos y pasta de cemento). El tiempo total de transmisión de un rayo ultrasónico en el concreto puede ser descompuesto como [3]: of the matter: gaseous phase (air), liquid phase (free water), and solid phase (fine and coarse aggregates, cement). The total transmission time $t$ of the ultrasonic ray in the acoustical system may be decomposed as [3]:

$$
t=t_{a}+t_{w}+t_{s}+\delta
$$

donde es considerado separadamente el intervalo de tiempo empleado por el rayo ultrasónico para viajar a través de cada fase en el medio heterogéneo: $t_{a}$ es el tiempo de propagación en el aire, $t_{w}$ es el tiempo de propagación en el agua libre, $\mathrm{y} \mathrm{t}_{\mathrm{s}}$ es el tiempo de propagación en la fase sólida; finalmente, $\delta$ es el intervalo de tiempo empleado por el rayo ultrasónico para viajar fuera de la pieza de prueba y que se considerará un valor constante durante todo el proceso de medición, $\delta=0,6 \mu \mathrm{s}$ (7). La ecuación [3] puede ser escrita como [4]: where it was separately considered the time interval spent by the ultrasonic ray for travelling through each phase in the heterogeneous medium: $t_{a}$ corresponds to the air, $t_{w}$ corresponds to the free water, and $t_{s}$ corresponds to the solid phase of concrete. Finally, $\delta$ represents the time interval spent by the ultrasonic ray for travelling outside the testing piece, and it will be considered a constant value during the measuring procedure on a given testing piece. Its numerical value in all these experiments was taken to be $\delta=0.6 \mu \mathrm{s}$ (7). The equation [3] may be written as [4]:

$$
t-\delta=\frac{h_{a}}{v_{a}}+\frac{h_{w}}{v_{w}}+\frac{h_{s}}{v_{s}}=\frac{h}{v}
$$

Donde $h_{a}, h_{w}, h_{s}$ son las longitudes equivalentes del recorrido del rayo ultrasónico en el aire, en el agua libre, y en la fase sólida, respectivamente. La cantidad h representa la longitud de la pieza de ensayo $(200 \mathrm{~mm}), \mathrm{v}_{\mathrm{a}}=$ $330 \mathrm{~m} / \mathrm{s}, \mathrm{v}_{\mathrm{w}}=1500 \mathrm{~m} / \mathrm{s}, \mathrm{v}_{\mathrm{s}}$ son las velocidades de propagación en cada fase, y $v$ es la velocidad efectiva de propagación del pulso ultrasónico en el material heterogéneo.

Cuando la muestra no exhibe humedad (estado seco), se puede considerar que $h_{w} / v_{w}=0$ en la ecuación [4] y el tiempo total de transmisión del rayo ultrasónico a través del sistema acústico toma su valor máximo, al cual corresponde el valor mínimo de la velocidad efectiva de la propagación del pulso ultrasónico en el sistema. Además cuando el aire está presente, la variable $h_{a}$ toma su valor máximo $h_{p}$ lo que corresponde a la longitud del camino del rayo ultrasónico en el espacio de poros. Por otro lado, si la pieza de ensayo está completamente saturada, entonces $h_{a} / v_{a}=0$ y $h_{w}=h_{p}$ y se obtiene el tiempo mínimo que corresponde con el valor máximo de la velocidad efectiva. En este análisis se asume que las cantidades $h_{s}, v_{s}$ y $h$ son fijas. También debe ocurrir que la cantidad $h_{w}+h_{a}=h_{p}$ es constante, al igual que $h_{p}+h_{\text {s. }}$ (14).

Las variables $t$ y $h_{w}$ en la ecuación [4] están bien definidas en los intervalos $t \in\left[t_{\max }, t_{\min }\right]$ y $h_{w} \in\left[0, h_{p}\right]$. La variable tiempo puede ser medida directamente pero $h_{w}$ no. Aquí se declara la hipótesis de que $h_{w}$ depende de la cantidad de agua libre $\mathrm{m}_{\mathrm{w}}$ en la muestra, aunque su dependencia no es simple. La manera en la cual $h_{w}$ depende where $h_{a} h_{w \prime} h_{s}$ are the ultrasonic ray path lengths in air, in free water, and in solid phase, respectively, $h$ is the testing piece length $(200 \mathrm{~mm}), v_{a}=330 \mathrm{~m} / \mathrm{s}, v_{w}=$ $1500 \mathrm{~m} / \mathrm{s}, v_{s}$ is the ultrasonic propagation velocity in the concrete solid phase, and finally, $v$ represents the effective ultrasonic propagation velocity in the heterogeneous medium.

When the testing piece does not exhibit moisture at all it can be considered that the term $h_{w} / v_{w}$ in the equation [4] is approximately equal to zero and the transition time $t$ of the ultrasonic ray through the testing piece takes its maximum value $t_{\max }$. It corresponds to a minimum value of the effective ultrasonic propagation velocity $v$ in the heterogeneous medium. Besides, the variable $h_{a}$ takes its maximum value $h_{p}$ which corresponds to the ultrasonic ray path length in porous space when only the air is present. On the other hand, if the testing piece is quite saturated with the free water, we can consider that the term $h_{a} / v_{a}$ in the equation [4] is approximately equal to zero, the variable $h_{w}$ takes its maximum value $h_{p}$, the variable $t$ takes its minimum value $t_{\min }$ corresponding to the maximum value of the variable $v$. We have assumed in the analysis above that the quantities $h_{s}, v_{s}$ and $h$ are fixed. It is also considered that $h_{w}+h_{a}=h_{p}$ is a constant, and similarly it happens to the quantity $h_{p}+h_{s}(14)$.

Variables $t$ and $h_{w}$ in the equation [4] are well defined in the intervals $t \in\left[t_{\text {max }}, t_{\text {min }}\right]$ and $h_{w} \in\left[0, h_{p}\right]$. The variable $t$ can be directly measured, but the variable $h_{w}$ can not. Here we considered that the variable $h_{w}$ depends on the quantity of free water $\left(m_{w}\right)$ in the testing piece, but such a dependence will not be a simple one. 
$\mathrm{m}_{\mathrm{w}}$ no es un asunto conocido para ser explicado teóricamente, pero se puede suponer que una dependencia tal es influenciada por la morfología de poros y por la ley de la distribución estadística de poros en el volumen de la pieza de ensayo, entre otros factores. Estos aspectos serán considerados en investigaciones posteriores. Sin embargo, puede afirmarse que las variables $h_{w}$ y $m_{w}$ están definidas en los intervalos respectivos $h_{w} \in\left[0, h_{p}\right]$ y $m_{w} \in\left[0, m_{w \prime m a x}\right]$. Se asume una relación empírica entre estas variables donde se introducen dos parámetros, $\mathrm{Q}>0$, constante dimensional, y $1>\gamma>0$, un exponente constante adimensional. Aplicando un método de regresión lineal a un gráfico log-log de los datos experimentales $\left(m_{w}, t_{\max }-t\right)$, la mejor línea recta ajustada a los puntos produce los valores esperados para los parámetros del modelo, $\gamma$ y Q, [5] (14). En este gráfico, el punto $(0,0)$ no puede ser tomado en consideración, y se obtiene el siguiente resultado numérico.
The way in which $h_{w}$ depends on $m_{w}$ is not a known matter for theoretical explaining, but we suppose that such a dependence is influenced by the morphology of pores and by the statistical distribution law of pores in the testing piece volume, among other factors. These aspects will be considered in further investigations. We know that the variable $h_{w}$ and the variable $m_{w}$ are well defined in the intervals $h_{w} \in\left[0, h_{p}\right]$ and $m_{w} \in[0$, $\left.m_{w r \max }\right]$. It was assumed an empirical relationship between these variables, where two parameters were introduced, $Q>0$, a dimensional constant, and $1>\gamma>0$, an exponential adimensional constant. Applying a linear regression method to a log-log plotting of the variables $\left(t_{\max }-t\right)$ and $\left(m_{w}\right)$ the best straight line is fitted to the experimental data points and the model parameters $\gamma$ and $Q,[5]$ (14) can be determined. In this plot, the point $(0,0)$ cannot be taken into account, and it was obtained the following numerical result.

$$
\begin{aligned}
& \gamma_{A-1}=0.8707 ; \gamma_{B-1}=0.9205 ; \gamma_{C-1}=0.7923 \\
& Q_{A-1}=0.0111 ; Q_{B-1}=0.01245 ; Q_{C-1}=0.0080
\end{aligned}
$$

\subsection{Ajuste de los datos experimentales}

Las cotas de error para las variables $t$ y $\mathrm{m}_{\mathrm{w}}$ y el parámetro $h$, medidas directamente, están dados en (7), en el que se utilizan tres muestras de ensayo: A-1, B-1, y C-1. Los datos experimentales fueron organizados como vectores de datos, lo cual facilitó el tratamiento posterior (14). Se obtuvo el promedio de los cinco valores del tiempo de propagación para cada valor del contenido de agua libre $m_{w}$ medidos en (7) como un elemento del vector de datos nombrado "time" ( $\mu \mathrm{s})$. El vector "water" contiene los valores de la variable $\mathrm{m}_{\mathrm{w}}(\mathrm{kg})$. Estos vectores constituyen el punto de partida para aplicar el procedimiento.

Se estima la cota de error aleatorio para el vector "time" y se compone conjuntamente con la cota de error instrumental, cuyo valor es igual a 0,2 $\mu \mathrm{s}$, para tener el vector "cota-time" en $\mu \mathrm{s}$. El vector "time" es corregido mediante el valor constante $\delta=0,6 \mu \mathrm{s}$, para obtener el vector "timec" en $\mu s$ (14). Utilizando este vector, el vector "velocity" es construido aplicando la relación [6]:

\subsection{Experimental data adjustments}

The cottas of error for the variables $t$ and $m_{w r}$ and the parameter $h$, all of them directly measured, are given in (7). There it was applied the procedure to each of three types of testing piece named $A-1, B-1$, and $C-1$. Besides, the experimental data points considered by us were organized as data vectors because it made easier data processing when certain software was used. Ohdaira and Masuzawa (7) measured the transition time $t$ five times for each value of the free water $m_{w}$. Statistical validation allows us to average these five values by taking the mean value as one element (in $\mu s$ ) of the data vector called "time". The vector "water" contains the values of the variable $m_{w}$ in kilogram.

We estimated the random cotta of error for the vector "time" and composed it together with the instrumental cotta of error whose value is equal to $0.2 \mu$ s for having the vector "cotta-time" in $\mu \mathrm{s}$. The vector "time" was corrected by the constant value $\delta=0.6 \mu$ s for obtaining the vector "timec" in $\mu s$ (14). By using the vector (timec) the vector "velocity" was determined by applying the relationship [6]:

$$
v=\frac{h}{(t-\delta)}
$$

donde $h$ es la longitud de cada pieza de ensayo y $t-\delta$ son los elementos del vector "timec". Los elementos del vector "velocity" están dados en m/s. Finalmente, las cotas de error para el tiempo de transmisión, vector "cotatime", y para la longitud de la pieza de ensayo where $h$ is the length of each testing piece and $t-\delta$ are the elements of the vector "timec". The elements of the vector "velocity" are given in $\mathrm{m} / \mathrm{s}$. Finally, the cotta of error for the transition time and for the length of the testing piece $(\delta h=0.0005 \mathrm{~m})$ were propagated $(14)$ 
$(\delta h=0.0005 \mathrm{~m})$ fueron propagadas (14) mediante la expresión [6], escrita en forma de incremento finito para obtener el vector "סvelocity" en m/s.

A1: $\delta v=[43,31,33,65,35,15,42,66,45,21,32,1$, $36,93,31,36,32,01,31,06,35,04,42,21,34,94,27,52$, 28,65]

$B 1: \delta v=[32,3,31,55,30,86,30,64,32,19,32,94,32,66$, $35,31,2,34,33,33,33,33,16,28,84,32,03,32,09$, 26,48]

$C 1: \delta v=[30,10,30,66,31,48,28,37,31,08,28,84$, $29,93,28,65,29,45,31,78,28,96,29,41,35,67,33,67$, $33,69,49,35,29,86]$

Teniendo en cuenta los valores de $\gamma$ y Q [5], se propone la relación de la velocidad del pulso ultrasónico con el contenido de agua para cada una de las dosificaciones (14).

En la figura 2, se muestra el ajuste de los datos experimentales a partir de la ecuación [7]. through the formula [6], written in the form of finite increment, to obtain the vector "svelocity" en $\mathrm{m} / \mathrm{s}$

A1: "Svelocity" $=[43.31,33.65,35.15,42.66,45.21$, $32.1,36.93,31.36,32.01,31.06,35.04,42.21$, 34.94, 27.52, 28.65]

B1: "Svelocity" $=[32.3,31.55,30.86,30.64,32.19$, $32.94,32.66,35,31.2,34.33,33.33,33.16,28.84$, $32.03,32.09,26.48]$

C1: "Svelocity" $=[30.10,30.66,31.48,28.37,31.08$, $28.84,29.93,28.65,29.45,31.78,28.96,29.41,35.67$, $33.67,33.69,49.35,29.86]$

By considering the values of de $\gamma$ y $Q$ [5], the effective ultrasonic pulse propagation velocity $v$ as a function of $m_{w}$ is given by (14).

Figure 2 shows the experimental data points and the fitting obtained by the equation [7].

$$
\begin{aligned}
& v_{A-1}=\frac{3943.2}{\left(1-(0.52524) m_{w}^{0.8707}\right)} \\
& v_{B-1}=\frac{3906.2}{\left(1-(0.58125) m_{w}^{0.9205}\right)} \\
& v_{C-1}=\frac{3810.9}{\left(1-(0.365854) m_{w}^{0.7923}\right)}
\end{aligned}
$$

Es importante verificar que el modelo propuesto describe correctamente el compor tamiento de los datos experimentales $\left(\mathrm{v}=\mathrm{f}\left(\mathrm{m}_{\mathrm{w}}\right)\right)$. Podemos linealizar la ecuación [7], si $m_{w}=0$, entonces la velocidad coincide con el valor de la velocidad mínima $\mathrm{v}_{0}$ (velocidad en estado seco) y consecuentemente la ecuación [7] se puede escribir de la siguiente forma [8]:
It is important to check whether the proposed model correctly describes the behavior of the experimental data points. In order to accomplish the analysis the equation [7] can be written in its general form [8]: donde $y=v$ es la velocidad efectiva de propagación del pulso ultrasónico, $a=v_{0}$ representa el valor mínimo de la velocidad (en estado seco), $\mathrm{x}=m_{\mathrm{w}}$ es el contenido de agua libre, $b=Q\left(k_{1} / k_{2}\right)$ y $c=\gamma$ son parámetros del modelo según la ecuación [7]. Cuando $x=0$, se obtiene que $y=a[8]$.

\subsection{Condición para la validez del modelo lineal}

Para analizar en qué condición el comportamiento de $v$ con $m_{w}$ se puede considerar una relación lineal, la ecuación [6] se escribe en su forma general (14) y aplicando la fórmula binomial de Newton se obtiene para la aproximación cuadrática [9]:

$$
y=\frac{a}{\left(1-b x^{C}\right)}
$$




$$
v^{(2)} \cong\left(\frac{h}{k_{2}}\right)\left(1+\left(Q k_{1} / k_{2}\right) m_{w}^{\gamma}+\left(Q k_{1} / k_{2}\right)^{2} m_{w}^{2 \gamma}\right), \ldots,\left(Q k_{1} / k_{2}\right) m_{w} \ll<1
$$

De esta relación se obtiene la contribución del término cuadrático para cada una de las dosificaciones consideradas, y se construye el vector "errorv" en $\mathrm{m} / \mathrm{s}$ para cada una de ellas (14).

$A-1:$ error $v=[82,28,69,64,61,79,54,08,47,55,34,29$, $27,12,21,02,12,52,8,15,4,18,1,77,0,28,0,0]$ B-1: error $v=[99,72,76,52,66,19,57,29,50,31,44,56$, $36,53,28,99,21,74,11,85,7,5,3,51,1,33,0,19,0,0]$ $\mathrm{C}-1$ : error $\mathrm{v}=[53,77,46,34,38,9,34,43,29,28,25,68$, $22,63,18,38,14,45,10,72,6,54,4,68,2,74,1,34,0,27,0,0]$

Se pueden comparar los vectores de datos "deltavelocidad" y "errorv" para decidir cuando el enfoque lineal es conveniente que sea aplicado.

\section{DISCUSIÓN DE LOS RESULTADOS}

La influencia de la humedad en la pieza de hormigón sobre la velocidad de propagación efectiva del pulso ultrasónico es altamente significativa, lo cual no indica necesariamente que haya cambiado el valor de la resistencia del material. La forma funcional mediante la cual esta influencia es determinada, depende de varios factores, entre los que están la morfología de poros y la ley de distribución estadística de poros en el volumen de la pieza de ensayo. En la Tabla 1 se presentan los resultados del ajuste de ambos modelos. Puede observarse que el modelo que mejor describe el proceso experimental es el modelo exponencial. No es posible hacer un análisis de los residuales (normalidad, homogeneidad de varianza, etc.) porque los datos experimentales son pocos y no hay criterios para invalidar ninguno de los dos modelos, por tanto el criterio de ajuste está dado por el coeficiente de regresión. En la Figura 1, se muestra el ajuste lineal según (7) y el ajuste no lineal propuesto. Teniendo en cuenta que el proceso de pérdida de agua es un proceso no lineal continuo hasta alcanzar el equilibrio entre la muestra y el medio, ocurriendo la mayor pérdida en los primeros momentos como resultado del gradiente de concentración. Esta es la razón por la cual en las tres dosificaciones la diferencia entre el valor inicial en estado saturado y el siguiente punto, es mucho mayor que entre el resto de los puntos experimentales, por lo que el primer punto queda fuera de la tendencia del proceso. Por este motivo, los primeros puntos experimentales deben ser medidos de forma casi continua para evitar cambios bruscos en los valores del contenido de agua y, por ende, de la velocidad de propagación del pulso ultrasónico que conduzcan a errores en la interpretación de los resultados.
From this equation the contribution of the quadratic term for each dosage can be obtained and the vector "error $v$ " in $\mathrm{m} / \mathrm{s}$ is constructed (14).

$A-1:$ errorv $=[82.28,69.64,61.79,54.08,47.55,34.29$,

$27.12,21.02,12.52,8.15,4.18,1.77,0.28,0.0]$

$B$-1: errorv $=[99.72,76.52,66.19,57.29,50.31,44.56$,

$36.53,28.99,21.74,11.85,7.5,3.51,1.33,0.19,0.0]$

$C-1$ : errorv $=[53.77,46.34,38.9,34.43,29.28,25.68$,

$22.63,18.38,14.45,10.72,6.54,4.68,2.74,1.34,0.27,0.0]$

We can compare the vectors "svelocity" and "errorv" for deciding when the linear approach is suitable to apply.

\section{DISCUSSION OF RESULTS}

The influence of moisture in the testing piece of concrete on the effective propagation velocity of ultrasonic pulse is highly significant, but it does not necessarily signify any changing in the value of the compression strength of the material. The functional form through which such an influence is determined depends, among other factors, on the morphology of pores and on the law of statistical distribution of pores in the testing piece volume. In the Figure 1 is depicted both joining the linear fitting according to (7) and the nonlinear mathematical fitting proposed. Table 1 shows the results of both fitting models. It can be seen from the data in that table that the exponential model describes the experimental process better than the linear model does. It is not possible to analyze here the residuals (normality, homogeneity of variance, etc) because the experimental data are scarce and there are no criteria to override any of the two models, therefore the criterion of fitting is given by the regression coefficient value. Because the process of water losing is a nonlinear one continuously until equilibrium between the sample and the environment is reached the most water losing takes place in the early stages as a result of the greatest concentration gradient. This is the reason why for each dosage, the difference between the initial saturated state and the next experimental point is higher than the difference between any other two successive points in the experimental plotting, so that the first point, corresponding to the saturated state, falls outside the trend of the process. For this reason the first experimental points should be measured almost continuously to avoid sudden changes in the values ??of the free water content and thus avoid too that the propagation velocity of the ultrasonic pulse leads to errors in the interpretation of results. 


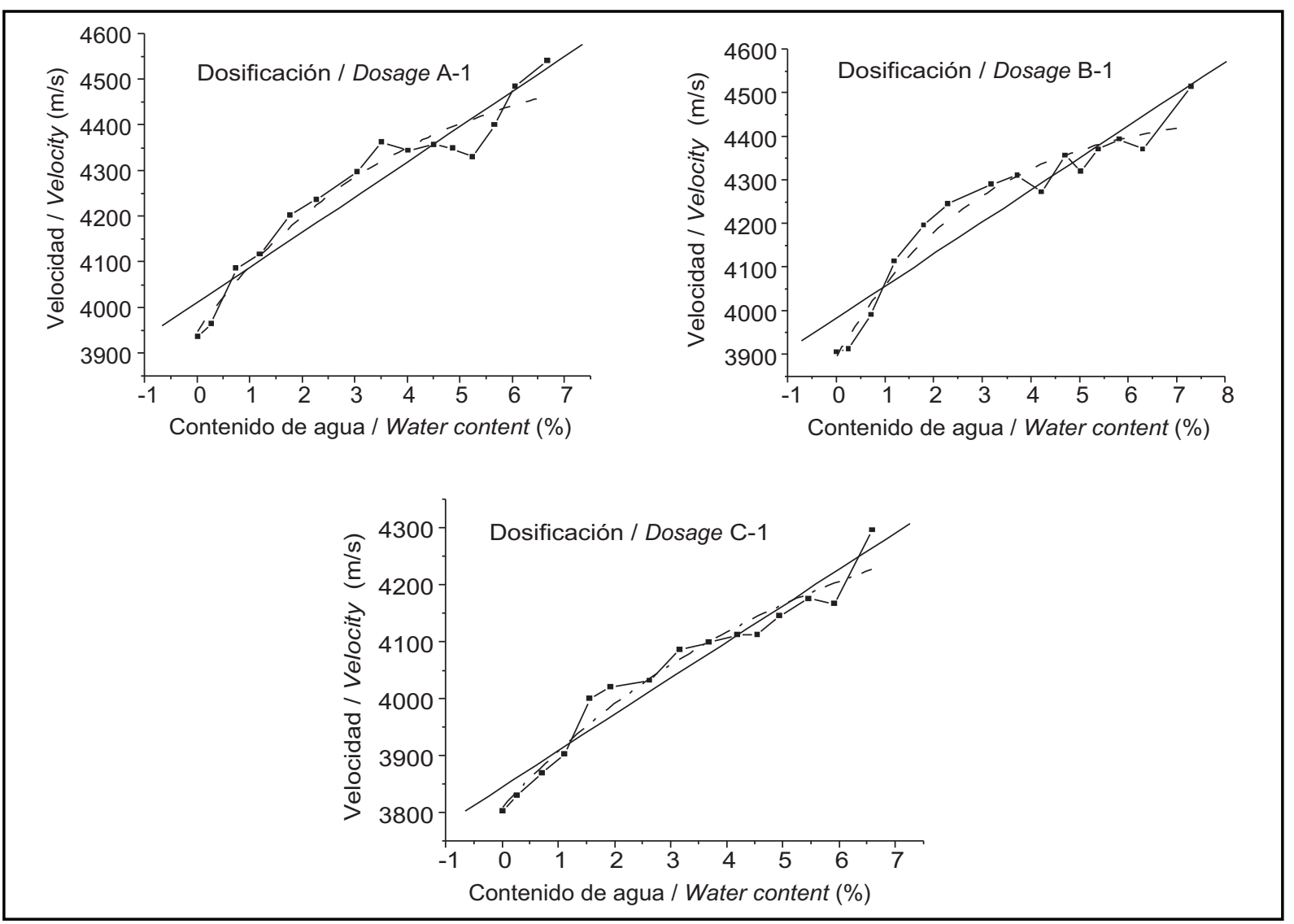

Figura 1. Velocidad de propagación del pulso ultrasónico vs. contenido de agua libre. Ajuste del modelo exponencial propuesto y el modelo lineal según (7).

Figure 1. Experimental curves of the behaviour of the propagation velocity of the ultrasonic pulse with the free water content, joining to the exponential model and linear model (7).

Tabla 1 / Table 1

Valores de los parámetros y coeficiente de correlación para los modelos estadísticos.

Values of parameters and correlation coefficients for the statistical models.

\section{Dosificación A-1 / A-1 Dosage}

Regresión no lineal / Non Linear Regression

\begin{tabular}{|c|c|c|c|c|}
\hline \multicolumn{5}{|c|}{ Estimados de los Parámetros / Parameter Estimates } \\
\hline \multirow{2}{*}{ Parámetro / Parameter } & \multirow{2}{*}{ Estimado / Estimate } & \multirow{2}{*}{ Error Standard / Std. Error } & \multicolumn{2}{|c|}{ 95\% Intervalo de Confidencia / Confidence Interval } \\
\cline { 3 - 5 } & & & Límite Inferior / Lower Bound & Límite Superior / Upper Bound \\
\hline y0 & 4464.831 & 46.905 & 4361.595 & 4568.067 \\
\hline A & -531.249 & 42.499 & -624.788 & -437.71 \\
\hline K & 2.642 & 0.609 & 1.302 & 3.982 \\
\hline
\end{tabular}

\begin{tabular}{|c|c|c|c|}
\hline \multicolumn{3}{|c|}{ Correlaciones de los Estimados de los Parámetros / Correlations of Parameter Estimates } \\
\hline & y0 & A & $\mathrm{K}$ \\
\hline $\mathrm{y} 0$ & 1.000 & -0.841 & 0.942 \\
\hline $\mathrm{K}$ & -0.841 & 1.000 & -0.681 \\
\hline
\end{tabular}

\begin{tabular}{|c|c|c|c|}
\hline \multicolumn{3}{|c|}{ ANOVA (a.) } \\
\hline Fuente / Source & $\begin{array}{c}\text { Suma de Cuadrados / } \\
\text { Sumo of Squares }\end{array}$ & $\begin{array}{c}\text { gl-Grados de Libertad / } \\
\text { df-Degree of Freedom) }\end{array}$ & $\begin{array}{c}\text { Cuadrados Medios / } \\
\text { Mean Squares }\end{array}$ \\
\hline Regresión / Regression & $3 \mathrm{E}+008$ & 3 & 4307662 \\
\hline Residual / Residual & 2917.605 & 11 & 1174.328 \\
\hline Total Incorrecto / Uncorrected Total & $3 \mathrm{E}+008$ & 14 & \\
\hline Total Correcto / Corrected Total & 355342.0 & 13 & \\
\hline
\end{tabular}

Velocidad Promedio / Variable Dependiente. a. R Cuadrada $=1$. (Suma de Cuadrados Residual) $/$ (Suma de Cuadrados Correcta) $=0,964$. / Mean Velocity / Dependent Variable. a. $R$ Squared = 1. (Residual Sum of Squares) / (Corrected Sum of Squares) $=0.964$. 
Tabla 1 / Table 1 (Cont.)

Valores de los parámetros y coeficiente de correlación para los modelos estadísticos.

Values of parameters and correlation coefficients for the statistical models.

Regresión lineal / Linear Regression

\begin{tabular}{|c|c|c|c|}
\hline \multicolumn{3}{|c|}{ Variables Entradas / Removidas / Variables Entered / Removed (b.) } \\
\hline Modelo / Model & Variables Entradas / Variables Entered & Variables Removidas / Variables Removed & Método / Method \\
\hline 1 & Contenido de agua / Water Content (a.) (\%) & & Enter \\
\hline
\end{tabular}

a. Variables Entradas / Todas Requeridas. b. Velocidad Promedio / Variable Dependiente. / a. Variables Entered / All Requested. b. Mean Velocity / Dependent Variable.

\begin{tabular}{|c|c|c|c|c|c|}
\hline \multicolumn{6}{|c|}{ Resumen del Modelo / Model Summary (b.) } \\
\hline $\begin{array}{c}\text { Modelo I } \\
\text { Model }\end{array}$ & $\mathbf{R}$ & R Cuadrado / $R$ Square & $\begin{array}{l}\text { R Cuadrado Ajustada / } \\
\text { Adjusted } R \text { Squared }\end{array}$ & $\begin{array}{l}\text { Error Standard del Estimado / } \\
\text { Std. Error of The Estimate }\end{array}$ & Durbin-Watson \\
\hline 1 & 0.947 (a.) & 0.898 & 0.889 & 5.053596 & 0.597 \\
\hline
\end{tabular}

a. Predictores: (Constante), Contenido de Agua (\%). b. Velocidad Promedio / Variable Dependiente. / a. Predictors: (Constant), Water Content (\%). b. Mean Velocity / Dependent Variable.

\begin{tabular}{|c|c|c|c|c|c|c|}
\hline \multicolumn{2}{|c|}{ ANOVA (b.) } \\
\hline \multicolumn{2}{|c|}{ Modelo / Model } & $\begin{array}{c}\text { Suma de Cuadrados I } \\
\text { Sum of Squares }\end{array}$ & $\begin{array}{c}\text { gl-Grados de Libertad / } \\
\text { df-Degree of Freedom }\end{array}$ & $\begin{array}{c}\text { Cuadrado Medio / } \\
\text { Mean Square }\end{array}$ & $\begin{array}{c}\text { Significación I } \\
\text { Signification) }\end{array}$ \\
\hline \multirow{3}{*}{1} & Regresión / Regression & 318971.2 & 1 & 318971.231 & 105.240 & 0.000 (a.) \\
\cline { 2 - 8 } & Residual / Residual & 36370.781 & 12 & 3030.898 & & \\
\cline { 2 - 8 } & Total & 355342.0 & 13 & & \\
\hline
\end{tabular}

a. Predictores: (Constante), Contenido de Agua (\%). b. Velocidad Promedio / Variable Dependiente. / a. Predictors: (Constant), Water Content (\%). b. Mean Velocity / Dependent Variable.

\begin{tabular}{|c|c|c|c|c|c|c|c|c|}
\hline \multicolumn{9}{|c|}{ Coeficientes / Coefficients (b.) } \\
\hline & \multirow{2}{*}{ Modelo / Model } & \multicolumn{2}{|c|}{$\begin{array}{l}\text { Coeficientes no } \\
\text { Estandarizados / } \\
\text { Unstandardized } \\
\text { Coefficients }\end{array}$} & \multirow{2}{*}{$\begin{array}{c}\text { Coeficientes } \\
\begin{array}{c}\text { Estandarizados } / \\
\text { Dtandardized } \\
\text { Coefficients }\end{array} \\
\text { Beta }\end{array}$} & \multirow[t]{2}{*}{$\mathbf{t}$} & \multirow[t]{2}{*}{ Sig. } & \multicolumn{2}{|c|}{$\begin{array}{c}\text { Intervalo de Confianza para I } \\
\text { Confidence Interval for }\end{array}$} \\
\hline & & B & $\begin{array}{c}\text { Error } \\
\text { Standard / } \\
\text { Std. Error }\end{array}$ & & & & $\begin{array}{c}\text { Límite } \\
\text { Inferior / } \\
\text { Lower Bound }\end{array}$ & \begin{tabular}{|c|} 
Límite \\
Superior I \\
Upper Bound
\end{tabular} \\
\hline 1 & $\begin{array}{c}\text { Constante / Constant } \\
\text { Contenido de Agua / Water Content }\end{array}$ & $\begin{array}{c}1013.572 \\
75.888\end{array}$ & $\begin{array}{c}27.140 \\
7.397\end{array}$ & 0.947 & $\begin{array}{c}147.884 \\
10.259\end{array}$ & $\begin{array}{l}0.000 \\
0.000\end{array}$ & $\begin{array}{c}3954.439 \\
59.771\end{array}$ & $\begin{array}{c}4072.705 \\
92.006\end{array}$ \\
\hline
\end{tabular}

a. Velocidad Promedio / Variable Dependiente. / a. Mean Velocity / Dependent Variable.

\begin{tabular}{|c|c|c|c|c|c|}
\hline \multicolumn{6}{|c|}{ Estadística de Residuales / Residuals Statistics (a.) } \\
\hline & Mínimo / Minimum & Máximo / Maximum & Media / Mean & Desviación Standard / Std. Deviation & $\mathbf{N}$ \\
\hline Valor Predicho / Predicted Value & 4013.572 & 4473.455 & 4247.525 & 156.640507 & 14 \\
\hline $\begin{array}{c}\text { Valor Predicho Standard / Std. } \\
\text { Predicted value }\end{array}$ & -1.494 & 1.442 & 0.000 & 1.000 & 14 \\
\hline $\begin{array}{c}\text { Error Standard del Valor Predicho / } \\
\text { Std. Error of predicted value }\end{array}$ & 14.717 & 27.140 & 20.391 & 4.302 & 14 \\
\hline $\begin{array}{c}\text { Valor Predicho Ajustado / Adjusted } \\
\text { predicted value }\end{array}$ & 4038.115 & 4470.159 & 4250.467 & 154.975151 & 14 \\
\hline Residual / Residual & -81.7518 & 81.400986 & 0.000000 & 52.893784 & 14 \\
\hline Residual Standard / Std. Residual & -1.485 & 1.479 & 0.000 & 0.961 & 14 \\
\hline Residual de Student / Stud. Residual & -1.616 & 1.537 & -0.025 & 1.043 & 14 \\
\hline Residual Eliminado / Deleted Residual & -100.990 & 87.989532 & -2.942104 & 62.466964 & 14 \\
\hline $\begin{array}{l}\text { Residual Eliminado de Student / } \\
\text { Stud. Deleted Residual }\end{array}$ & -1.749 & 1.642 & -0.042 & 1.090 & 14 \\
\hline Distancia de Mahal. / Mahal. Distance & 0.000 & 2.231 & 0.929 & 0.771 & 14 \\
\hline Distancia de Cook / Cook's Distance & 0.000 & 0.409 & 0.094 & 0.125 & 14 \\
\hline $\begin{array}{c}\text { Valor Nivelado Centrado / Centered } \\
\text { Leverage Value }\end{array}$ & 0.000 & 0.172 & 0.071 & 0.059 & 14 \\
\hline
\end{tabular}

a. Velocidad Promedio / Variable Dependiente. / a. Mean Velocity / Dependent Variable.

Dosificación B-1 / B-1 Dosage

Regresión no lineal / Non linear Regression

\begin{tabular}{|c|c|c|c|c|}
\hline \multicolumn{5}{|c|}{ Estimados de los Parámetros / Parameter Estimates } \\
\hline \multirow{2}{*}{$\begin{array}{c}\text { Parámetro / } \\
\text { Parameter }\end{array}$} & \multirow{2}{*}{$\begin{array}{c}\text { Estimado I } \\
\text { Estimate }\end{array}$} & \multirow{2}{*}{$\begin{array}{l}\text { Error Standard / } \\
\text { Std. Error }\end{array}$} & \multicolumn{2}{|c|}{ 95\% Intervalo de Confidencia / Confidence Interval } \\
\hline & & & Límite Inferior / Lower Bound & Límite Superior / Upper Bound \\
\hline y0 & 4397.356 & 24.929 & 4342.489 & 4452.224 \\
\hline A & -517.464 & 26.041 & -574.780 & -460.148 \\
\hline K & 2.083 & 0.326 & 1.365 & 2.801 \\
\hline
\end{tabular}


Tabla 1 / Table 1 (Cont.)

Valores de los parámetros y coeficiente de correlación para los modelos estadísticos.

Values of parameters and correlation coefficients for the statistical models.

\begin{tabular}{|c|c|c|c|}
\hline \multicolumn{4}{|c|}{ Correlaciones de los Estimados de los Parámetro / Correlations of Parameter Estimates } \\
\hline & y0 & A & $\mathbf{K}$ \\
\hline y0 & 1.000 & -0.646 & 0.893 \\
\hline A & -0.646 & 1.000 & -0.378 \\
\hline K & 0.893 & -0.378 & 1.000 \\
\hline \multicolumn{4}{|c|}{ ANOVA (a.) } \\
\hline Fuente / Source & $\begin{array}{l}\text { Suma de Cuadrados I } \\
\text { Sumo of Squares }\end{array}$ & $\begin{array}{l}\text { gl-Grados de Libertad / } \\
\text { df-Degree of Freedom) }\end{array}$ & $\begin{array}{c}\text { Cuadrados Medios I } \\
\text { Mean Squares }\end{array}$ \\
\hline Regresión / Regression & $2 \mathrm{E}+008$ & 3 & 83185607 \\
\hline Residual / Residual & 8803.709 & 11 & 800.337 \\
\hline Total Incorrecto / Uncorrected Total & $2 \mathrm{E}+008$ & 14 & \\
\hline Total Correcto / Corrected Total & 377563.1 & 13 & \\
\hline
\end{tabular}

Velocidad Promedio / Variable Dependiente. a. R Cuadrada = 1. (Suma de Cuadrados Residual) / (Suma de Cuadrados Correcta) = 0.977. / Mean Velocity / Dependent Variable. a. $R$ Squared $=1$. (Residual Sum of Squares) / (Corrected Sum of Squares) = 0.977.

Regresión lineal / Linear Regression

\begin{tabular}{|c|c|c|c|}
\hline \multicolumn{4}{|c|}{ Variables Entradas / Removidas / Variables Entered / Removed (b.) } \\
\hline Modelo / Model & Variables Entradas / Variables Entered & Variables Removidas / Variables Removed & Método / Method \\
\hline 1 & Contenido de agua / Water Content (a.) (\%) & & Entrada / Enter \\
\hline
\end{tabular}

a. Variables Entradas / Todas Requeridas. b. Velocidad Promedio / Variable Dependiente. / a. Variables Entered / All Requested. b. Mean Velocity / Dependent Variable.

\begin{tabular}{|c|c|c|c|c|c|}
\hline \multicolumn{5}{|c|}{ Resumen del Modelo / Model Summary (b.) } \\
\hline Modelo / Model & R & R Cuadrado / R Square & $\begin{array}{c}\text { R Cuadrado Ajustada / } \\
\text { Adjusted R Squared }\end{array}$ & $\begin{array}{c}\text { Error Standard del Estimado / } \\
\text { Std. Error of The Estimate }\end{array}$ & \begin{tabular}{c} 
Durbin-Watson \\
\hline 1
\end{tabular} \\
\hline
\end{tabular}

a. Predictores: (Constante), Contenido de Agua (\%). b. Velocidad Promedio / Variable Dependiente. / a. Predictors: (Constant), Water Content (\%). b. Mean Velocity / Dependent Variable.

\begin{tabular}{|c|c|c|c|c|c|c|}
\hline \multicolumn{7}{|c|}{ ANOVA (b.) } \\
\hline & Modelo / Model & $\begin{array}{l}\text { Suma de Cuadrados I } \\
\text { Sum of Squares }\end{array}$ & $\begin{array}{l}\text { gl-Grados de Libertad / } \\
\text { df-Degree of Freedom }\end{array}$ & $\begin{array}{l}\text { Cuadrado Medio I } \\
\text { Mean Square }\end{array}$ & $\mathbf{F}$ & $\begin{array}{l}\text { Significación I } \\
\text { Signification) }\end{array}$ \\
\hline \multirow{3}{*}{1} & Regresión / Regression & 327753.0 & 1 & 327752.975 & 78.961 & 0.000 (a.) \\
\hline & Residual / Residual & 49810.132 & 12 & 4150.844 & & \\
\hline & Total & 377563.1 & 13 & & & \\
\hline
\end{tabular}

a. Predictors: (Constant), Water Content (\%). b. Mean Velocity / Dependent Variable. / a. Predictors: (Constant), Water Content (\%). b. Mean Velocity / Dependent Variable.

\begin{tabular}{|c|c|c|c|c|c|c|c|c|}
\hline \multicolumn{9}{|c|}{ Coeficientes / Coefficients (b.) } \\
\hline & \multirow{2}{*}{ Modelo / Model } & \multicolumn{2}{|c|}{\begin{tabular}{|c|} 
Coeficientes no \\
Estandarizados I \\
Unstandardized Coefficients
\end{tabular}} & \multirow{2}{*}{\begin{tabular}{|c|}
$\begin{array}{c}\text { Coeficientes } \\
\text { Estandarizados } / \\
\text { Standardized Coefficients }\end{array}$ \\
Beta
\end{tabular}} & \multirow[t]{2}{*}{$\mathbf{t}$} & \multirow[t]{2}{*}{$\begin{array}{l}\text { Significación / } \\
\text { Signification }\end{array}$} & \multicolumn{2}{|c|}{$\begin{array}{l}\text { Intervalo de Confianza } \\
\text { para / Confidence } \\
\text { Interval for }\end{array}$} \\
\hline & & B & $\begin{array}{l}\text { Error Standard / } \\
\text { Std. Error }\end{array}$ & & & & $\begin{array}{c}\text { Límite } \\
\text { Inferior / } \\
\text { Lower Bound }\end{array}$ & \begin{tabular}{|c|} 
Límite \\
Superior I \\
Upper Bound
\end{tabular} \\
\hline 1 & $\begin{array}{c}\text { Constante / Constant } \\
\text { Contenido de agua / Water Content }\end{array}$ & $\begin{array}{c}3984.350 \\
73.742\end{array}$ & $\begin{array}{l}31.516 \\
8.299\end{array}$ & 0.932 & $\begin{array}{c}126.425 \\
8.886\end{array}$ & $\begin{array}{l}0.000 \\
0.000\end{array}$ & $\begin{array}{c}3915.684 \\
55.661\end{array}$ & $\begin{array}{c}4053.017 \\
91.824\end{array}$ \\
\hline
\end{tabular}

a. Velocidad Promedio / Variable Dependiente. / a. Mean Velocity / Dependent Variable.

\begin{tabular}{|c|c|c|c|c|c|}
\hline \multicolumn{6}{|c|}{ Estadística de Residuales / Residuals Statistics (a.) } \\
\hline & Mínimo / Minimum & Máximo / Maximum & Media / Mean & Desviación Standard / Std. Deviation & $\mathbf{N}$ \\
\hline Valor Predicho / Predicted value & 3984.350 & 4448.927 & 4218.904 & 158.782138 & 14 \\
\hline $\begin{array}{l}\text { Valor Predicho Standard / } \\
\text { Std. Predicted value } \\
\end{array}$ & -1.477 & 1.449 & 0.000 & 1.000 & 14 \\
\hline $\begin{array}{l}\text { Error Standard del Valor Predicho / } \\
\text { Standard Error of Predicted Value }\end{array}$ & 17.219 & 31.516 & 23.880 & 4.948 & 14 \\
\hline $\begin{array}{c}\text { Valor Predicho Ajustado / Adjusted } \\
\text { Predicted Value }\end{array}$ & 4008.885 & 4472.384 & 4222.893 & 157.667417 & 14 \\
\hline Residual / Residual & -87.5986 & 93.304741 & 0.000000 & 61.899504 & 14 \\
\hline Residual Standard / Std. Residual & -1.360 & 1.448 & 0.000 & 0.961 & 14 \\
\hline Residual de Student / Stud. Residual & -1.535 & 1.514 & -0.028 & 1.045 & 14 \\
\hline Residual Eliminado / Deleted Residual & -111.578 & 101.9269 & -3.989441 & 73.392650 & 14 \\
\hline $\begin{array}{l}\text { Residual Eliminado de Student / } \\
\text { Stud. Deleted Residual }\end{array}$ & -1.639 & 1.611 & -0.031 & 1.083 & 14 \\
\hline Distancia de Mahal. / Mahal. Distance & 0.000 & 2.182 & 0.929 & 0.758 & 14 \\
\hline Distancia de Cook / Cook's Distance & 0.000 & 0.322 & 0.097 & 0.117 & 14 \\
\hline $\begin{array}{c}\text { Valor Nivelado Centrado / Centered } \\
\text { Leverage Value }\end{array}$ & 0.000 & 0.168 & 0.071 & 0.058 & 14 \\
\hline
\end{tabular}

a. Velocidad Promedio / Variable Dependiente. / a. Mean Velocity / Dependent Variable. 
Tabla 1 / Table 1 (Cont.)

Valores de los parámetros y coeficiente de correlación para los modelos estadísticos.

Values of parameters and correlation coefficients for the statistical models.

Dosificación C-1 / C-1 Dosage

Regresión no lineal / Non Linear Regression

\begin{tabular}{|c|c|c|c|c|}
\hline \multicolumn{5}{|c|}{ Estimados de los Parámetros / Parameter Estimates } \\
\hline Parámetro I & Estimado I & Error Standard I & \multicolumn{2}{|c|}{ 95\% Intervalo de Confidencia / Confidence Interval } \\
\cline { 3 - 5 } Parameter & Estimate & Límite Inferior / Lower Bound & Límite Superior / Upper Bound \\
\hline y0 & 4414.597 & 151.330 & 4084.878 & 4744.316 \\
\hline $\mathrm{A}$ & -604.652 & 140.762 & -911.346 & -297.957 \\
\hline $\mathrm{K}$ & 5.617 & 2.357 & 0.482 & 10.752 \\
\hline
\end{tabular}

\begin{tabular}{|c|c|c|c|}
\hline \multicolumn{3}{|c|}{ Correlaciones de los Estimados de los Parámetro / Correlations of Parameter Estimates } \\
\hline & y0 & A & \multicolumn{1}{c|}{ K } \\
\hline $\mathrm{y} 0$ & 1.000 & -0.992 & 0.987 \\
\hline $\mathrm{A}$ & -0.992 & 1.000 & -0.965 \\
\hline $\mathrm{K}$ & 0.987 & -0.965 & 1.000 \\
\hline
\end{tabular}

\begin{tabular}{|c|c|c|c|}
\hline \multicolumn{3}{|c|}{ ANOVA (a.) } \\
\hline Fuente / Source & $\begin{array}{c}\text { Suma de Cuadrados I } \\
\text { Sumo of Squares }\end{array}$ & $\begin{array}{c}\text { gl-Grados de Libertad / } \\
\text { df-Degree of Freedom) }\end{array}$ & $\begin{array}{c}\text { Cuadrados Medios I } \\
\text { Mean Squares }\end{array}$ \\
\hline Regresión / Regression & 2E+008 & 3 & 81821156 \\
\hline Residual / Residual & 11939.693 & 12 & 994.974 \\
\hline Total Incorrecto / Uncorrected Total & $2 \mathrm{E}+008$ & 15 & \\
\hline Total Correcto / Corrected Total & 277766.3 & 14 & \\
\hline
\end{tabular}

Velocidad Promedio / Variable Dependiente. a. R Cuadrada = 1. (Suma de Cuadrados Residual) / (Suma de Cuadrados Correcta) $=0,957$. / Mean Velocity / Dependent Variable. a. $R$ Squared $=1$. (Residual Sum of Squares) $/($ Corrected Sum of Squares $)=0.957$.

Regresión lineal / Linear Regression

\begin{tabular}{|c|c|c|c|}
\hline \multicolumn{5}{|c|}{ Variables Entradas / Removidas / Variables Entered / Removed (b.) } \\
\hline Modelo / Model & Variables Entradas / Variables Entered & Variables Removidas / Variables Removed & Método / Method \\
\hline 1 & Contenido de agua / Water Content (a.) (\%) & & Entrada / Enter \\
\hline
\end{tabular}

a. Variables Entradas / Todas Requeridas. b. Velocidad Promedio / Variable Dependiente. / a. Variables Entered / All Requested. b. Mean Velocity / Dependent Variable.

\begin{tabular}{|c|c|c|c|c|c|}
\hline \multicolumn{5}{|c|}{ Resumen del Modelo / Model Summary (b.) } \\
\hline Modelo / Model & R & R Cuadrado / R Square & $\begin{array}{c}\text { R Cuadrado Ajustada / } \\
\text { Adjusted R Squared }\end{array}$ & $\begin{array}{c}\text { Error Standard del Estimado / } \\
\text { Std. Error of The Estimate }\end{array}$ & Durbin-Watson \\
\hline 1 & 0.969 (a.) & 0.940 & 0.935 & 35.894627 & 0.992 \\
\hline
\end{tabular}

a. Predictores: (Constante), Contenido de Agua (\%). b. Velocidad Promedio / Variable Dependiente. / a. Predictors: (Constant), Water Content (\%). b. Mean Velocity / Dependent Variable.

\begin{tabular}{|c|c|c|c|c|c|c|}
\hline \multicolumn{9}{|c|}{ ANOVA (b.) } \\
\hline \multirow{2}{*}{ Modelo / Model } & $\begin{array}{c}\text { Suma de Cuadrados I } \\
\text { Sum of Squares }\end{array}$ & $\begin{array}{c}\text { gl-Grados de Libertad / } \\
\text { df-Degree of Freedom }\end{array}$ & $\begin{array}{c}\text { Cuadrado Medio / } \\
\text { Mean Square }\end{array}$ & $\begin{array}{c}\text { Significación / } \\
\text { Signification) }\end{array}$ \\
\hline \multirow{3}{*}{1} & Regresión / Regression & 261016.8 & 1 & 261016.794 & 202.586 & 0.000 (a.) \\
\cline { 2 - 8 } & Residual / Residual & 16749.515 & 13 & 1288.424 & & \\
\cline { 2 - 8 } & Total & 277766.3 & 14 & & & \\
\hline
\end{tabular}

a. Predictors: (Constant), Water Content (\%). b. Mean Velocity / Dependent Variable. / a. Predictors: (Constant), Water Content (\%). b. Mean Velocity / Dependent Variable.

\begin{tabular}{|c|c|c|c|c|c|c|c|c|}
\hline \multicolumn{9}{|c|}{ Coefficients (b.) } \\
\hline & \multirow{2}{*}{ Modelo / Model } & \multicolumn{2}{|c|}{$\begin{array}{l}\text { Coeficientes no } \\
\text { Estandarizados / } \\
\text { Unstandardized } \\
\text { Coefficients }\end{array}$} & \multirow{2}{*}{$\begin{array}{c}\text { Coeficientes } \\
\text { Estandarizados / } \\
\text { Standardized } \\
\text { Coefficients } \\
\text { Beta }\end{array}$} & \multirow[t]{2}{*}{$\mathrm{t}$} & \multirow[t]{2}{*}{\begin{tabular}{|} 
Significación / \\
Signification
\end{tabular}} & \multicolumn{2}{|c|}{$\begin{array}{l}\text { Intervalo de Confianza } \\
\text { para / Confidence } \\
\text { Interval for }\end{array}$} \\
\hline & & B & $\begin{array}{c}\text { Error Standard / } \\
\text { Std. Error }\end{array}$ & & & & $\begin{array}{c}\text { Límite } \\
\text { Inferior / } \\
\text { Lower Bound }\end{array}$ & $\begin{array}{l}\text { Límite } \\
\text { Superior I } \\
\text { Upper Bound }\end{array}$ \\
\hline 1 & $\begin{array}{c}\text { Constante / Constant } \\
\text { Contenido de agua / Water Content }\end{array}$ & $\begin{array}{c}3844.593 \\
63.864\end{array}$ & $\begin{array}{c}16.744 \\
4.487\end{array}$ & 0.969 & $\begin{array}{r}229.607 \\
14.233\end{array}$ & $\begin{array}{l}0.000 \\
0.000\end{array}$ & $\begin{array}{c}3808.420 \\
54.170\end{array}$ & $\begin{array}{l}3880.767 \\
73.557\end{array}$ \\
\hline
\end{tabular}

a. Velocidad Promedio / Variable Dependiente. / a. Mean Velocity / Dependent Variable. 
Tabla 1 / Table 1 (Cont.)

Valores de los parámetros y coeficiente de correlación para los modelos estadísticos. Values of parameters and correlation coefficients for the statistical models.

\begin{tabular}{|c|c|c|c|c|c|}
\hline \multicolumn{7}{|c|}{ Estadística de Residuales / Residuals Statistics (a.) } \\
\hline & Mínimo / Minimum & Máximo / Maximum & Media / Mean & Desviación Standard / Std. Deviation & N \\
\hline Valor Predicho / Predicted value & 3844.539 & 4265.455 & 4043.082 & 136.543241 & 15 \\
\hline $\begin{array}{c}\text { Valor Predicho Standard / } \\
\text { Std. Predicted value }\end{array}$ & -1.454 & 1.629 & 0.000 & 1.000 & 15 \\
\hline $\begin{array}{c}\text { Error Standard del Valor Predicho / } \\
\text { Standard Error of Predicted Value }\end{array}$ & 9.271 & 18.166 & 12.819 & 2.825 & 15 \\
\hline $\begin{array}{c}\text { Valor Predicho Ajustado / Adjusted } \\
\text { Predicted Value }\end{array}$ & 3856.307 & 4254.775 & 4044.243 & 135.293073 & 15 \\
\hline Residual / Residual & -54.5892 & 56.543026 & 0.000000 & 34.588928 & 15 \\
\hline Residual Standard / Std. Residual & -1.521 & 1.575 & 0.000 & 0.964 & 1.042 \\
\hline Residual de Student / Stud. Residual & -1.688 & 1.665 & -0.015 & 40.516314 & 15 \\
\hline Residual Eliminado / Deleted Residual & -67.2673 & 63.148086 & -1.161739 & 1.087 & 15 \\
\hline $\begin{array}{c}\text { Residual Eliminado de Student / } \\
\text { Stud. Deleted Residual }\end{array}$ & -1.836 & 1.803 & -0.008 & 0.824 & 15 \\
\hline Distancia de Mahal. / Mahal. Distance & 0.001 & 2.652 & 0.933 & 0.100 & 15 \\
\hline Distancia de Cook / Cook's Distance & 0.000 & 0.331 & 0.089 & 0.059 & 15 \\
\hline $\begin{array}{c}\text { Valor Nivelado Centrado / Centered } \\
\text { Leverage Value }\end{array}$ & 0.000 & 0.189 & 0.067 & & 15 \\
\hline
\end{tabular}

a. Velocidad Promedio / Variable Dependiente. / a. Mean Velocity / Dependent Variable.

En la Figura 2 se muestran las curvas correspondientes a las ecuaciones [7] para las tres dosificaciones consideradas. Para comprobar la validez del modelo propuesto [7], se linealiza a través de [8] y se obtiene la siguiente expresión [10]:
Figure 2 shows the curves corresponding to equations [7] for the three dosages considered. To check whether the physical model proposed does correctly describe the behavior of the experimental data points the equation [8] is written as [10]:

$$
\ln \left(\frac{y-a}{a}\right)=\ln b^{\prime}+C \ln x ; \quad b^{\prime}=\frac{b}{a}
$$

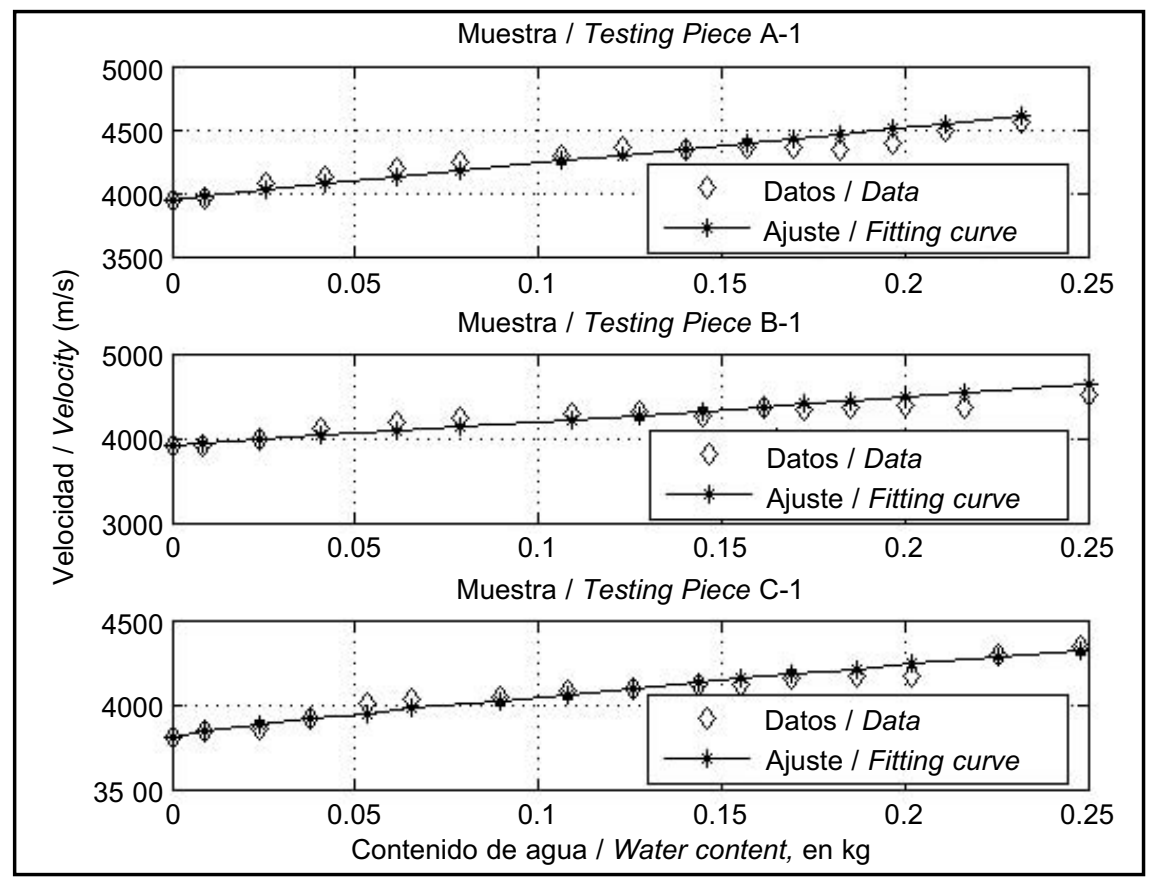

Figura 2. Dependencia de la velocidad de propagación del pulso ultrasónico y el contenido de agua libre y ajuste por el modelo físico simple.

Figure 2. Dependence of ultrasonic pulse velocity with free water content and simple physical model fit. 
En la Tabla 2 se muestran los resultados de la linealización del modelo. Se puede observar que el valor Durbin- Watson es relativamente bajo. Al existir autocorrelación entre los datos experimentales, el valor del contenido de agua libre y en consecuencia el de la velocidad de propagación en cada probeta, depende del valor anterior, o sea, una misma muestra en intervalos diferentes de tiempo. Además los valores obtenidos del parámetro $\mathrm{C}$ para cada dosificación no difieren significativamente del valor de $\gamma$ obtenido en [5]. Por tanto podemos concluir que el modelo propuesto en [7] describe correctamente el comportamiento de los datos experimentales.
From this linearized model the statistical analysis was carried out and the results are shown in the Table 2. One can see that the Durbin-Watson value is relatively low. As there is some autocorrelation between the experimental data points the value of free water content and consequently the propagation velocity in each testing piece depend on the previous value, i.e., the same sample at different intervals of time. In addition, the values of the parameter $C$ for each dosage did not differ significantly from the value of $\gamma$ obtained in [5]. We can therefore conclude that the model proposed in [7] does correctly describe the behavior of the experimental data points.

Tabla 2 / Table 2

Ajuste lineal del modelo físico simple [7] aplicando la transformación [10] para las tres dosificaciones. Linear fitting of the simple physical model [7] applying the transform [10].

Muestra A-1 / Test Piece A-1

\begin{tabular}{|c|c|c|c|c|c|c|c|c|}
\hline \multicolumn{2}{|r|}{$\mathbf{R}$} & $\begin{array}{l}\text { R Cuadrado / } \\
\text { R Square }\end{array}$ & \multicolumn{2}{|c|}{$\begin{array}{l}\text { R Cuadrado Ajustado I } \\
\text { Adjusted R Square }\end{array}$} & \multicolumn{2}{|c|}{$\begin{array}{l}\text { Error Típico del Estimado I } \\
\text { Typical Error of the Estimate }\end{array}$} & \multicolumn{2}{|c|}{ Durbin-Watson } \\
\hline & .955 & .912 & .905 & & .26315 & & & 1.187 \\
\hline & $\begin{array}{c}\text { Coeficientes no } \\
\text { Estadarizados I Non } \\
\text { Standardized } \\
\text { Coefficients } \\
\end{array}$ & & $\begin{array}{c}\text { Coeficientes } \\
\text { Estadarizados I } \\
\text { Standardized } \\
\text { Coefficients } \\
\end{array}$ & $\mathrm{t}$ & $\begin{array}{l}\text { Significación / } \\
\text { Signification }\end{array}$ & \multicolumn{2}{|c|}{$\begin{array}{c}\text { Intervalo de } \\
\text { Confianza I } \\
\text { Confidence } \\
\text { Interval } 95 \% \\
\end{array}$} & \\
\hline & B & Error Típico / Typ. Error & Beta & & & \multicolumn{2}{|c|}{$\begin{array}{l}\text { Límite Inferior / } \\
\text { Lower bound }\end{array}$} & $\begin{array}{l}\text { Límite Superior / } \\
\text { Upper bound }\end{array}$ \\
\hline Ln $b^{\prime}$ & -8.944 & .197 & & -45.314 & .000 & \multicolumn{2}{|c|}{-9.374} & -8.514 \\
\hline$C$ & .870 & .078 & .955 & 11.177 & .000 & \multicolumn{2}{|c|}{.700} & 1.040 \\
\hline
\end{tabular}

Muestra B-1 / Test Piece B-1

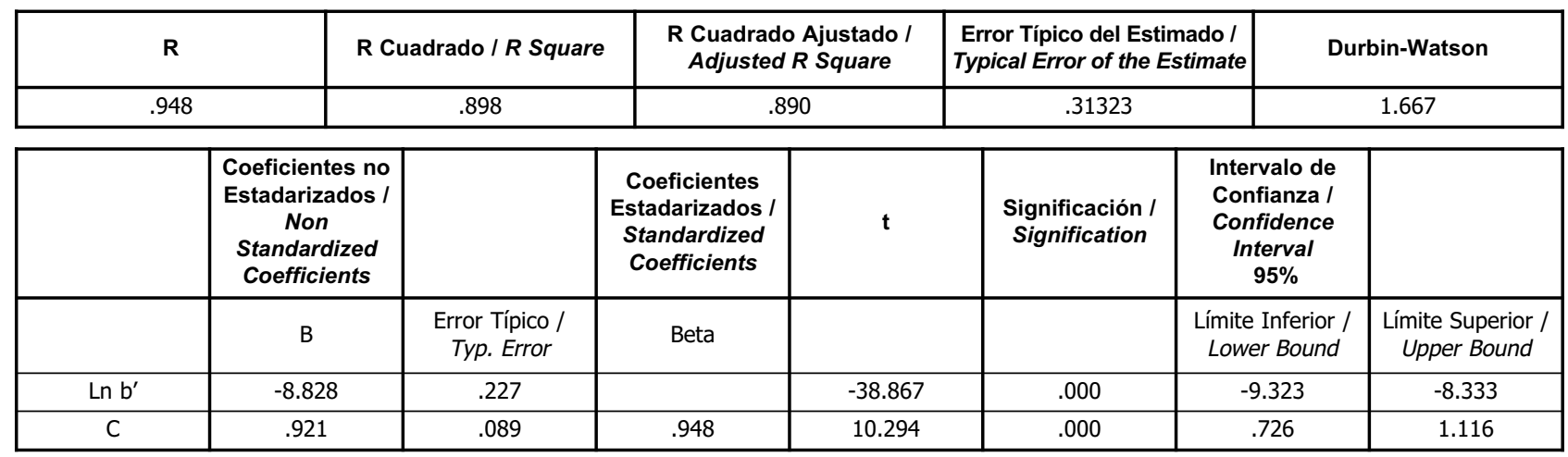

Muestra C-1 / Test Piece C-1

\begin{tabular}{|c|c|c|c|c|c|c|c|c|}
\hline \multirow[b]{2}{*}{.9} & \multicolumn{2}{|c|}{ R Cuadrado / $R$ Squaree } & \multicolumn{2}{|c|}{$\begin{array}{l}\text { R Cuadrado Ajustado / } \\
\text { Adjusted R Square }\end{array}$} & \multicolumn{2}{|c|}{$\begin{array}{l}\text { Error Típico del Estimado / } \\
\text { Typical Error of the Estimate }\end{array}$} & \multicolumn{2}{|c|}{ Durbin-Watson } \\
\hline & \multicolumn{2}{|r|}{.955} & \multicolumn{2}{|c|}{.951} & \multicolumn{2}{|l|}{.16846} & \multicolumn{2}{|r|}{1.265} \\
\hline & $\begin{array}{l}\text { Error Típico del } \\
\text { Estimado I } \\
\text { Typical Error of } \\
\text { the Estimate }\end{array}$ & & $\begin{array}{l}\text { Coeficientes } \\
\text { Estadarizados / } \\
\text { Standardized } \\
\text { Coefficients }\end{array}$ & $\mathbf{t}$ & $\begin{array}{l}\text { Significación / } \\
\text { Signification }\end{array}$ & \multicolumn{2}{|c|}{$\begin{array}{c}\text { Intervalo de } \\
\text { Confianza I } \\
\text { Confidence } \\
\text { Interval } \\
95 \%\end{array}$} & \\
\hline & B & $\begin{array}{l}\text { Error Típico / } \\
\text { Typical Error }\end{array}$ & Beta & & & \multicolumn{2}{|c|}{$\begin{array}{l}\text { Límite Inferior / } \\
\text { Lower Bound }\end{array}$} & $\begin{array}{l}\text { Límite Superior / } \\
\text { Upper Bound }\end{array}$ \\
\hline $\operatorname{Ln} b^{\prime}$ & -9.271 & .122 & & -75.767 & .0000 & \multicolumn{2}{|c|}{-9.535} & -9.006 \\
\hline $\mathrm{C}$ & .793 & .048 & .977 & 16.557 & .000 & .68 & & .896 \\
\hline
\end{tabular}


Se puede comparar los vectores "deltavelocidad" y "errorv" para decidir cuando el enfoque lineal es conveniente que sea aplicado. En la Figura 3 se muestra el comportamien-

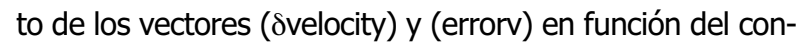
tenido de agua libre. A partir de cierto valor umbral $m_{\mathrm{w} 0}$ $\left(\mathrm{m}_{\mathrm{w} 0}=0,14 \mathrm{~kg}\right.$ para A -1 y B-1, y $m_{w 0}=0,17 \mathrm{~kg}$ para C$1), y$, en adelante, la contribución del término cuadrático supera la cota de error propagada para el valor experimental de la velocidad efectiva del pulso ultrasónico. Si se toma sólo hasta el término lineal en la ecuación [9], y con $\gamma \cong 1$, se describe aproximadamente bien el comportamiento lineal considerado en (7), pero esto implica un error mayor en la velocidad por el efecto cuadrático a partir del valor umbral de $m_{\mathrm{w}}$, tal y como se ha indicado.
We can compare the vectors (dvelocity) and (errorv) for deciding when the linear approach is suitable to apply. Figure 3 shows the behavior of vectors (dvelocity) and (errorv) with the free water content, $m_{w}$. After a certain threshold value $m_{w 0}\left(m_{w 0}=0.14 \mathrm{~kg}\right.$ for $A-1$ and $B-1$, and $m_{w 0}=0.17 \mathrm{~kg}$ for $(-1)$, and thereafter at all, it can be observed that the contribution of the quadratic term in the equation [9] is greater than the propagated cotta of error for the experimental value of the effective ultrasonic pulse propagation velocity. The equation [9], considering that the exponent $\gamma \cong 1$, approximately well describes the linear behavior considered in [7], but this approach implies a greater error in velocity when $m_{w}$ is greater than $m_{w 0}$.

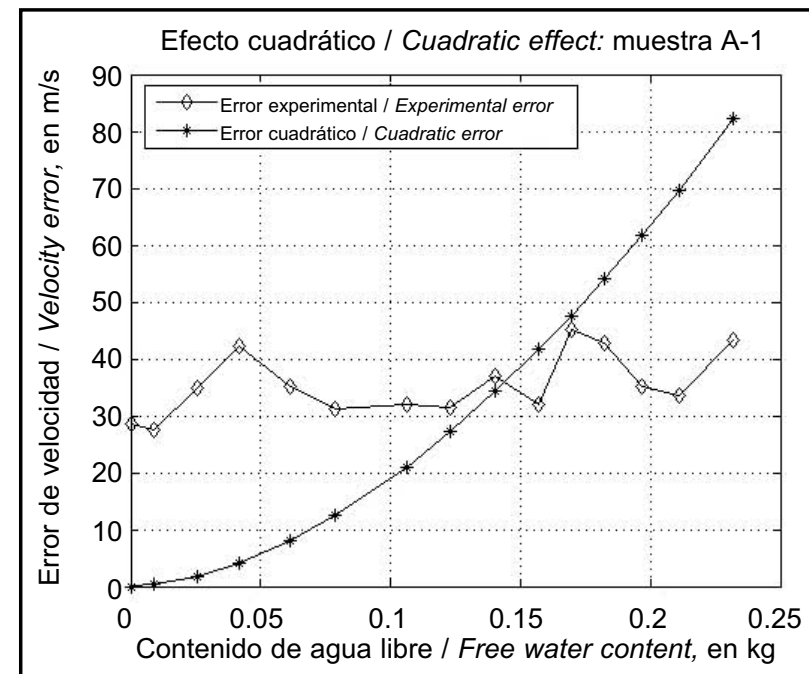

Efecto cuadrático / Cuadratic effect: muestra B-1

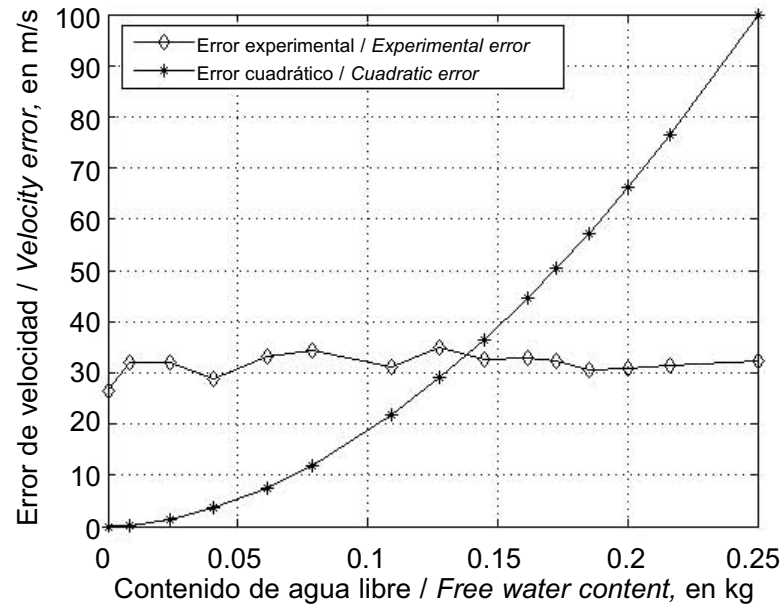

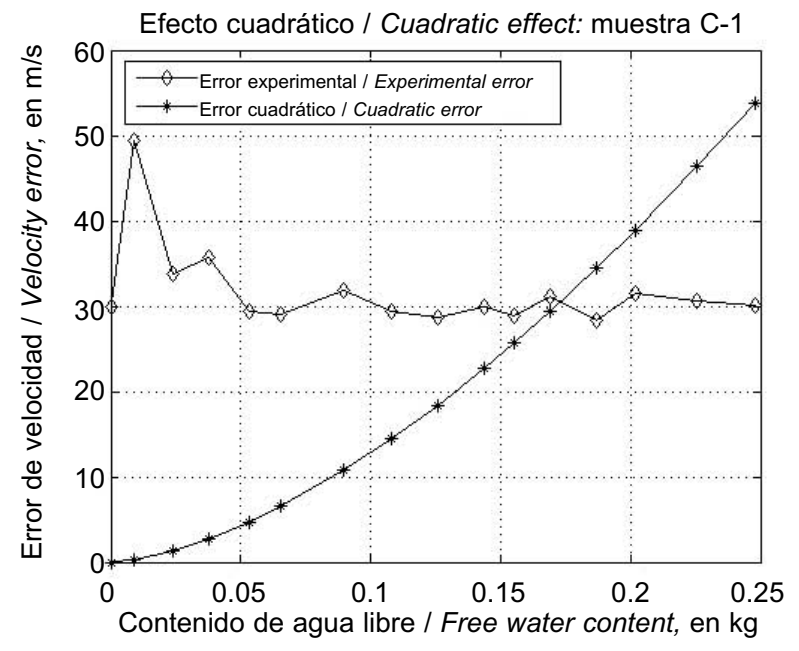

Figura 3. Comparación del efecto cuadrático del modelo con el error producido experimentalmente. Figure 3. Comparison of cuadratic effect and experimental error.

\section{CONCLUSIONES}

Los resultados confirman que la función de ajuste del modelo matemático tiene muy buena correlación con los datos experimentales y que el modelo físico simple,

\section{CONCLUSIONS}

The results shown here confirm that the fitting function of the mathematical model has a very good correlation with experimental data points and that the simple 
derivado de consideraciones geométricas y físicas, también describe correctamente el comportamiento de los datos experimentales. De esta forma, se puede afirmar que el comportamiento de los valores medidos de la velocidad de propagación del pulso ultrasónico con el contenido de agua libre, se expresa mejor por un enfoque no lineal. Esto se reafirma porque a partir de cierto valor del contenido de agua libre en la probeta el efecto no lineal de la dependencia es más fuerte que el correspondiente valor de la cota de error experimental para la velocidad. physical model, derived from geometrical and physical considerations, also does correctly describe the behavior of the experimental data points. At this point, it can be said that the behavior of the measured values of the propagation velocity of ultrasonic pulse with the free water content is better expressed by a nonlinear approach than by a linear one. This criterion is reinforced by the fact that thereafter a certain threshold value of the free water content, $m_{w 0}$, the nonlinear effect of the dependence is greater than the corresponding value of the propagated cotta of error for the experimental value of the effective ultrasonic pulse propagation velocity.

\section{BIBLIOGRAFÍA / BIBLIOGRAPHY}

(1) Río, L. M.; Jiménez, A.; López, F.; Rufo, M. M.; Paniagua, J. M : "Characterization and hardening of concrete with ultrasonic testing" Ultrasonics, volume 42, Issues 1-9 April (2004), pp. 527-530, Proceedings of Ultrasonics International 2003.

(2) Gozde Ozerkan, N.; Yaman Ozgur, I.: "Evaluation of cement mortars by ultrasound". $4^{\text {th }}$ Middle East NDT Conference and Exhibitions, Kingdom of Baharain, 2007.

(3) Del Río, L. M.; López, F.; Pareja, C.; Callejas, B.. "An ultrasound study of concrete hardening in construction pillars", 19 th International Congress on Acoustics, Madrid, September 2007.

(4) Malhotra, V. M.; Carino, N. J.: "CRC handbook on Non Destructive testing of concrete" N.J CRC Press, Boca Raton Florida (1991).

(5) Sandor, P.: "The behavior of ultrasonic pulse in concrete", Cem. Concr. Res., vol. 20.Issues 2, March (1990), pp. 259-270.

(6) Rodríguez, M.: "Influencia de la humedad del concreto sobre el valor de la velocidad del pulso ultrasónico", Cemento-Hormigón. España. Marzo (1999), no 795, p. 243.

(7) Etsuzo, O.; Nobuyoshi, M.: "Water content and effect on ultrasound propagation in concrete - the possibility of NDE", Ultrasonics, volume 38, Issues1-8, March (2000), pp. 546-552.

(8) Zhou, D.; Xiaozhou, L.; Xiufen, G.: "Water content diagnostic of concrete using Non linear acoustic means". $17^{\text {th }}$ World Conference on Non Destructive Testing Octuber 2008, Shangai, China.

(9) Martys, N. S.: "Survey of Concrete Transport Properties and Their Measu rement". US Department of Commerce Technology Administration National Institute of Standards and Technology, Glthersburg MD 20899, February (1995).

(10) Rafik, B.; Menghao, Q.; Abdelkarin, A. M.: "Modeling of transport in Porous building materials by gravimetric sorption-desorption tests". Annex 41, Moist-Eng, working meeting, April 3-5 (2006), Kyoto, Japan.

(11) Qin, S. C.; Chen, D.; Wang, H.: "Simultaneous heat and moisture transfer in concrete with time-dependent boundary conditions", Magazine of Concrete Research (2008), 60 no 10 December 725-733. http://dx.doi.org/10.1680/macr.2008.00021

(12) Wonlwosen, A. B. S. C. E.: "Finite Element temperature development and moisture diffusion prediction models for concrete at early ages using Matlab", A Thesis in Civil Engineering, Master of Science in Civil Engineering. Texas Tech University (2010).

(13) Mukhopadhyay, A. K.; Ye, D.; Zollinger, D.: "Moisture-Related Cracking effects on Hydratating concrete pavement", Texas Transportation Institute, Report 0-1700-6, Project 0-1700 (2006).

(14) Fadragas, C. R.; Rodríguez, M.; Bonal, R.: "Modelling the propagation of a ultrasonic ray through a heterogeneous medium", NDT. net, vol. 8, no 11,(2003). 